$$
\begin{aligned}
& \text { 괭생이모자반 젖산 추출물이 성장기 암컷흰쥐의 } \\
& \text { 골 형성에 미치는 영향 } \\
& \text { 전준영·이수영·김병목 }{ }^{1} \text { 정인학** } \\
& \text { 강릉원주대학교 해양식품공학과, }{ }^{1} \text { 한국식품연구원 }
\end{aligned}
$$

\title{
Effect of Lactic Acid Extracts of Sargassum horneri on Bone Formation in Female Sprage-Dawley Rats
}

\author{
Joon-young Jun, Su-young Lee, Byeng-mok Kim ${ }^{1}$ and In-hak Jeong* \\ Department of Marine Food Science and Technology, \\ Gangneung-Wonju National University, Gangwon 210-702, Korea \\ ${ }^{I}$ Korea Food Research Institute, Gyeonggi 463-746, Korea
}

We investigated the effect of a lactic acid extract of Sargassum horneri (ExSL) as a calcium supplement on bone formation in 48 female Sprague-Dawley rats for 4 weeks of their growth phase. The rats were divided into four groups based on diet: two calcium-sufficient and two calcium-deficient diets. The normal control group (NC) was fed AIN-93G; the NCS group was fed the same diet containing 1\% extract; the calcium-deficient control (DC) diet was based on AIN-93G; and the DCS group received the same calcium-deficient diet plus $1 \%$ extract. Bone formation in the rats was evaluated using the wet weight, length, diameter, and bone mineral density (BMD) of the femur. Serum parameters were also examined. The food intake among the groups did not differ significantly $(P<0.05)$. The NCS group gained the most body weight, while the DC group gained much less weight than the other groups. The feeding efficiencies of the groups that received the extract (NCS and DCS) were slightly higher than those of the control groups (NC and DC). The calcium intakes of all groups depended on the amount of calcium in the feed; the NCS and DCS diets contained 12-15 mg more calcium than the NC and DC diets. The calcium absorption was lower in NCS than in DC and DCS, but significantly higher than in NC $(P<0.05)$. The BMDs in the calcium-sufficient groups were not significantly different $(P<0.05)$, while in the calcium-deficient groups the BMD was significantly higher in DCS than in DC $(P<0.05)$. The serum calcium and phosphorus levels in all groups were not associated with markers of bone growth related to the extract. The osteocalcin content and alkaline phosphatase (ALPase) activity were higher in the calcium-deficient groups than in the normal groups $(P<0.05)$. Ultimately, the osteocalcin content and ALPase activity were lower in DCS compared to DC. These results suggest that the addition of ExSL promotes bone formation and calcium absorption in growing rats.

Key words: Calcium intakes, Bone mineral density, Calcium absorption, Calcium supplement, Sargassum horneri, Rat

서 론

우리나라 국민영양조사결과 $(\mathrm{KCDCP}, 2008)$ 단백질, 지방 질 등 에너지 섭취는 꾸준히 증가하여 필요량 이상을 섭취하 고 있는 반면, 무기질 중 칼슘의 섭취는 필요권장량의 $75 \%$ 미 만에 불과하다. 특히, $13 \sim 19$ 세의 청소년의 경우에는 $50 \%$ 미만 으로 장래 이들이 장년에 이르렀을 때에는 심각한 건강상의 문제를 초래할 수 있는 위협이 될 수 있다.

성장기 동안에는 최대 골량에 도달하게 되며 연속적으로 노화와 관련되어 골 손실이 진행된다. 골 형성에는 유전, 노화, 체중, 민족성 같은 변화시킬 수 없는 요인과 식이, 생리적 활동수준, 흡연, 술 등의 변화시킬 수 있는 생활형태적 요인이 있다 (Weaver, 2000). 생활형태적 요인의 조절과 꾸준한 식품

*Corresponding author: ihjeong@gwnu.ao.kr
을 통한 칼슘섭취는 성장기 동안의 최대 골 생성량을 증진시 키며, 위와 같은 위험을 예방하는 주요 전략이 될 수 있다. 육상에 존재하는 다양한 무기질은 바다로 유입되며, 해조 는 성장과정 중 그 무기질을 조체에 농축하게 된다. 현재, 해조를 이용하여 칼슘공급원으로 사용해 보고자 시도하는 연구가 다수 있으며 (Bougle et al., 1996, Lee et al., 2002), 해조가 칼슘대사에 긍정적인 영향을 미친다는 결과 또한 나타 나고 있다 (Yamaguchi et al., 2001, Kwak and Kim, 2010). 그 중에서도 갈조류에 속하는 괭생이 모자반은 해조 가운데 비교적 회분함량이 높고 (Cho et al, 1995, Ruperez, 2002), 대형 갈조류로 군락을 형성하기 때문에 손쉽게 재배될 수 있는 장점을 지니고 있는데도 불구하고, 현재, 식품으로서의 이용 도는 현저히 낮은 편이다.

따라서, 해조의 식품학적 가치를 높이는 측면에서 괭생이 
모자반을 무기질 식품공급원으로 이용해 보고자 본 실험을 진행하였다. 젖산은 다양한 유기산 중에서 칼슘의 흡수에 긍 적적으로 작용할 뿐 만아니라 (Levrat et al., 1991) 추출수율을 향상시킬 수 있을 것으로 기대된다. 먼저, 괭생이 모자반으로 부터 젓산 추출물을 제조하였고, 암컷흰쥐를 대상으로 그들의 성장기 동안 충분한 칼슘을 공급 받았을 때와 그러지 못하였 을 경우를 가정한 후 괭생이 모자반 젖산추출물 첨가가 흰쥐 의 골 형성에 미치는 영향을 살펴보았다.

\section{재료 및 방법}

괭생이 모자반 젖산추출물

괭생이 모자반 (Sargassum horneri)은 강원도 강릉시 사근 진 연안에서 4 6월 사이 채취한 것으로 증류수로 가볍게 수세 한 후 음건하였다. 음건된 괭생이 모자반은 $90^{\circ} \mathrm{C}, 0.11 \%(\mathrm{v} / \mathrm{v})$ 젖산용액에서 24 시간 동안 추출하였고, $5 \mu \mathrm{m}$ 이하로 여과 후 진공 동결건조하여 분말화하였다.

일반성분과 무기질조성

추출물의 일반성분은 $\mathrm{AOAC}$ 법 $(\mathrm{AOAC}, 1990)$ 에 따라 분석 하였고, 무기질조성은 추출물을 $60 \%$ 질산으로 분해 후 탈 이온수로 희석하여 유도결합 플라즈마 원자방출 분광기 (ICP-AES, Perkinelmer, USA)로 측정하였다.

Table 1. Diet compositions of experimental groups

\begin{tabular}{|c|c|c|c|c|}
\hline \multirow{3}{*}{ Ingredient } & \multicolumn{4}{|c|}{ Group } \\
\hline & \multicolumn{2}{|c|}{ Normal } & \multicolumn{2}{|c|}{$\begin{array}{c}\text { Calcium } \\
\text { deficiency }\end{array}$} \\
\hline & NC ${ }^{1}$ & NCS & DC & DCS \\
\hline Corn starch & 397.486 & 393.551 & 397.486 & 393.551 \\
\hline Casein & 200.000 & 198.020 & 200.000 & 198.020 \\
\hline Dextrinized corn starch & 132.000 & 130.693 & 132.000 & 130.693 \\
\hline Sucrose & 100.000 & 99.010 & 100.000 & 99.010 \\
\hline Soybean oil & 70.000 & 69.307 & 70.000 & 69.307 \\
\hline Fiber & 50.000 & 49.505 & 50.000 & 49.505 \\
\hline Mineral mix (Normal) & 35.000 & 34.653 & - & - \\
\hline Mineral mix (Calcium deficiency) & - & - & 35.000 & 34.653 \\
\hline Vitamin mix & 10.000 & 9.901 & 10.000 & 9.901 \\
\hline L-cystine & 3.000 & 2.970 & 3.000 & 2.970 \\
\hline Choline bitartrate & 2.500 & 2.475 & 2.500 & 2.475 \\
\hline Tert-butylhydroquinone & 0.014 & 0.014 & 0.014 & 0.014 \\
\hline Sargassum horneri extract & - & 9.901 & - & 9.901 \\
\hline
\end{tabular}

All diets were based on the AIN-93G formulation. NC, AIN-93G formulation as a positive control; NCS, Sargassum extract addition into the $\mathrm{NC}$ formulation; DC, calcium deficiency based AIN-93G formulation as a negative control; DCS, Sargassum extract addition into the DC formulation.
Table 2. Proximate and mineral compositions of the Sargassum extract

\begin{tabular}{lcrlr}
\hline & \multicolumn{3}{c}{ Content $^{1}$} & \multicolumn{1}{c}{ Content } \\
\hline \multirow{2}{*}{ Chemical } & Moisture & $7.02 \pm 0.89$ & Ash & $36.46 \pm 0.37$ \\
composition & Protein & $14.48 \pm 0.33$ Lipid & $0.77 \pm 0.55$ \\
& Carbohydrate & $41.27 \pm 2.14$ & \\
\hline Macro & $\mathrm{Na}$ & $3.97 \pm 0.47$ & $\mathrm{Ca}$ & $0.96 \pm 0.17$ \\
mineral & $\mathrm{K}$ & $10.60 \pm 0.15$ & $\mathrm{Mg}$ & $1.87 \pm 0.09$ \\
\hline \multirow{4}{*}{ Micro } & $\mathrm{Be}$ & $<0.001$ & $\mathrm{Se}$ & $3.03 \pm 1.02$ \\
mineral & $\mathrm{Co}$ & $0.63 \pm 0.04$ & $\mathrm{Ti}$ & $1.60 \pm 0.16$ \\
& $\mathrm{Cr}$ & $3.35 \pm 0.18 \mathrm{~V}$ & $2.38 \pm 1.26$ \\
& $\mathrm{Cu}$ & $14.94 \pm 1.09$ & $\mathrm{Zn}$ & $19.07 \pm 0.66$ \\
& $\mathrm{Fe}$ & $67.66 \pm 1.27$ & $\mathrm{Sr}$ & $460.40 \pm 10.21$ \\
& $\mathrm{Li}$ & $1.37 \pm 0.09$ & $\mathrm{Si}$ & $117.87 \pm 17.47$ \\
& $\mathrm{Mn}$ & $197.65 \pm 0.35$ & $\mathrm{Ag}$ & $<0.001$ \\
& $\mathrm{Mo}$ & $1.23 \pm 0.02$ & $\mathrm{Ba}$ & $2.20 \pm 0.19$ \\
& $\mathrm{Ni}$ & $2.28 \pm 0.07$ & $\mathrm{~B}$ & $188.35 \pm 1.08$ \\
& $\mathrm{Sb}$ & $<0.001$ & $\mathrm{Tl}$ & $<0.01$ \\
\hline
\end{tabular}

${ }^{1}$ The Unit of chemical composition and macro mineral content were expressed as $\mathrm{g}$ of $100 \mathrm{~g}$, and the unit of micro mineral content was expressed as $\mathrm{mg}$ of $\mathrm{kg}$.

\section{실험동물과 사료조성}

실험동물은 SLC사 (Shinzuoka, Japan)로부터 공급받은 3주 령 암컷흰쥐 (Sprague-Dawley Rat, female) 48 마리를 대상으로 하였다. AIN-93G조성의 사료로 일주일 동안 적응기간을 가졌 고, 성장기 설치류에서 가장 이상적인 조성으로 알려진 $\mathrm{AIN}-93 \mathrm{G}$ 조성을 Normal Control $(\mathrm{NC})$ 군으로, 칼슘이 결핍된 AIN-93G Calcium Deficiency조성을 Deficiency Control (DC) 군으로, $\mathrm{NC}$ 군과 $\mathrm{DC}$ 군 조성에 추출물이 각각 $1 \%$ 가 되도록 첨가하여 $\mathrm{NCS}$ 군, $\mathrm{DCS}$ 군 총 4 군으로 나누었다. 실험동물은 1 cage에 3마리씩, 4주 동안 사육하였다 (Table 2). 사육실의 환경은 온도 $22 \pm 2{ }^{\circ} \mathrm{C}$, 상대습도 $50 \pm 5 \%$, Light와 Dark cycle을 12 시간으로 일정하게 유지하였고, 사료와 탈이온수는 자유급 식형태로 공급하였다. 사료섭취량은 일주일에 2회, 체중은 일주일에 1 회 일정 시간에 측정하였고, 사료혼합을 위한 재료 는 Dyets사 (Bethlehem, PA, USA)의 것을 사용하였다.

\section{시료수집}

실험종료 전 2회에 걸쳐 실험동물을 대사 cage로 옮겨 24시 간 동안 변과 뇨를 수집하였다. 수집된 변은 $105^{\circ} \mathrm{C}$ 에서 건조하 였고, 뇨는 cage 당 $100 \mathrm{~mL}$ 이 되도록 탈 이온수로 희석하여 분석 전까지 $-20^{\circ} \mathrm{C}$ 에서 보관하였다. 실험동물은 희생 전 12 시 간 동안 절식하였고, 혈액은 ether 마취 후 심장으로부터 수집 되었다. 수집된 혈액은 즉시 $3,000 \mathrm{rpm}, 4^{\circ} \mathrm{C}$ (VS- $15 \mathrm{CFN}$, Vision, Korea)에서 20분간 원심분리하여 혈청으로 얻어졌다. 골 밀도 (bone mineral density, $\mathrm{BMD}$ ) 및 골 무기질함량 (bone mineral content, $\mathrm{BMC}$ ) 검사를 위하여 대퇴부를 적출 한 후 근육, 인대, 지방 등을 전부 제거하여 대퇴골을 얻었다. 


\section{시료분석}

대변과 소변의 칼슘량은 시료를 $60 \%$ 질산에 분해 후 탈 이온수로 희석하여 원자흡수 분광광도계 (AAS, Perkinelmer, USA)로 분석하였다. 대퇴골의 길이와 직경은 Digital caliper (500-181, Mtutoyo, Japan)로 측정하였고, 골 밀도와 골 무기질 함량은 Dual energy X-ray absorptiometry (Norland, USA)로 측정하였다. 혈청칼슘함량은 $\mathrm{OCPC}$ 법, 인함량은 비색법, alkaline phosphatase (ALPase) 활성은 Enzyme rate법으로 Hitachi 7170 Autoanalyzer (Hitachi, Japan)로 측정하였으며, Osteocalcin 함량은 Radio immuno법으로 CBRA II Auto-gamma counter (Packard, USA)로 측정하였다.

\section{통계분석}

평균과 표준편차는 SPSS program 2001을 이용하여 계산하 였고, One-way ANOVA test를 실시한 후, 최소 유의차 검정에 의해 평균간의 유의차를 $95 \%$ 유의수준 $\quad(P<0.05)$ 에서 Duncan's multiple range test에 의해 검정하였다.

\section{결 과}

괭생이 모자반 젖산추출물의 일반성분과 무기질조성 괭생이 모자반 젖산추출물은 수분 $7.02 \%$, 회분 $36.46 \%$, 단 백질 $14.48 \%$, 지질 $0.77 \%$, 탄수화물 $41.27 \%$ 로 구성되어 있었 다. 다량무기질은 추출물 $100 \mathrm{~g}$ 당 $\mathrm{Na} 3.97 \mathrm{~g}, \mathrm{~K} 10.60 \mathrm{~g}, \mathrm{Ca}$ $0.96 \mathrm{~g}, \mathrm{Mg} 1.87 \mathrm{~g}$ 으로 분석되었다. 미량무기질은 추출물 1 $\mathrm{kg}$ 당 $\mathrm{mg}$ 단위로 $\mathrm{Sr}(460.40 \mathrm{mg} / \mathrm{kg}), \mathrm{Mn}(197.65 \mathrm{mg} / \mathrm{kg}), \mathrm{B}$ $(188.35 \mathrm{mg} / \mathrm{kg}), \mathrm{Si}(117.87 \mathrm{mg} / \mathrm{kg})$ 가 대부분을 차지하였고, $\mathrm{Fe}, \mathrm{Zn}, \mathrm{Cu}, \mathrm{Se}$ 등 20 여종의 다양한 무기질이 존재하는 것으로 나타났다.

\section{사료섭취량, 체중증가량, 사료효율}

4주 동안의 사료섭취량, 체중증가량, 사료효율은 Fig. 1로 나타내었다. 사료섭취량은 정상사료 대조군인 $\mathrm{NC}$ 군이 $369.60 \pm 46.76 \mathrm{~g}$ 으로 가장 높게, 칼슘결핍사료 대조군인 $\mathrm{DC}$ 군 이 $340.76 \pm 37.80 \mathrm{~g}$ 으로 가장 낮게 나타나 약간의 차이를 보였 다. 하지만, 모든 그룹간 사료섭취량은 통계적 유의차가 없었 다. 체중증가량은 추출물이 첨가된 $\mathrm{NCS}$ 군 $(106.03 \pm 4.88 \mathrm{~g})$ 이 가장 높게, $\mathrm{DC}$ 군 $(85.00 \pm 8.04 \mathrm{~g})$ 이 가장 낮게 나타났고, $\mathrm{NC}$ 군 $(98.00 \pm 7.77 \mathrm{~g})$ 과 $\mathrm{DCS}$ 군 $(93.45 \pm 5.50 \mathrm{~g})$ 사이에는 유의적인 차 이가 없었다. 사료효율은 체중증가량을 사료섭취량으로 나누 어 구해졌으며, $\mathrm{NCS}$ 군 (0.29), $\mathrm{NC}$ 군 (0.27), DCS군 (0.26), DC 군 $(0.25)$ 순으로 높게 나타났다.

\section{칼슘섭취량과 흡수율}

대사기간 동안의 칼슘섭취량과 흡수율은 Fig. 2로 나타내었 다. 칼슘섭취량과 흡수율은 실제 사료에 존재하는 칼슘량을 바탕으로 계산되어 졌으며, 각 사료의 칼슘함량은 $\mathrm{NC}$ 군 $0.72 \%, \mathrm{NCS}$ 군 $0.83 \%, \mathrm{DC}$ 군 $0.10 \%, \mathrm{DCS}$ 군 $0.22 \%$ 였다. 암컷흰 쥐 한 마리가 하루 동안 섭취하는 칼슘량은 정상사료 대조군 (NC)이 $110.21 \pm 13.29 \mathrm{mg}$ 으로 칼슘결핍사료 대조군 (DC)

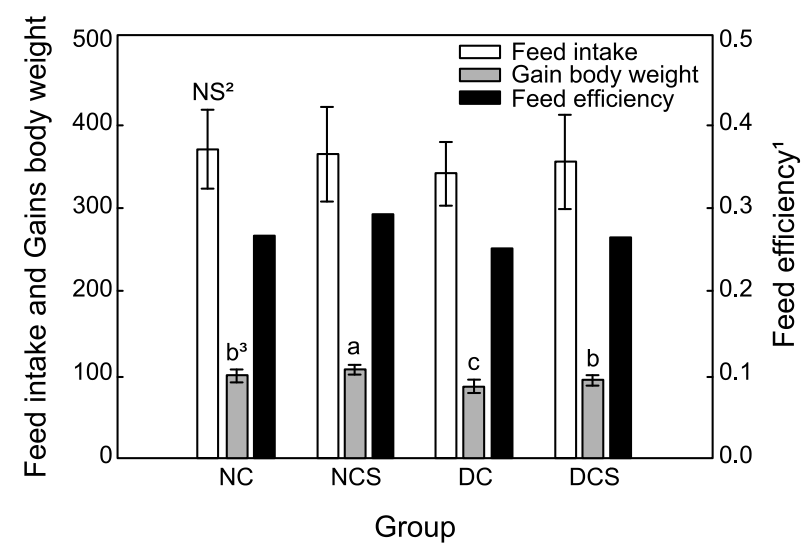

Fig. 1. Feed intake, gain body weight and feed efficiency of a rat for $4 \mathrm{wks}$, All data were expressed as mean \pm SD of 12 rats per a group.; 1 This value was calculated as 'gain body weight/feed intake'; 2 Not significant at $P<0.05 ; 3$ Values within column with different superscript letters are significantly different at $P<0.05$.

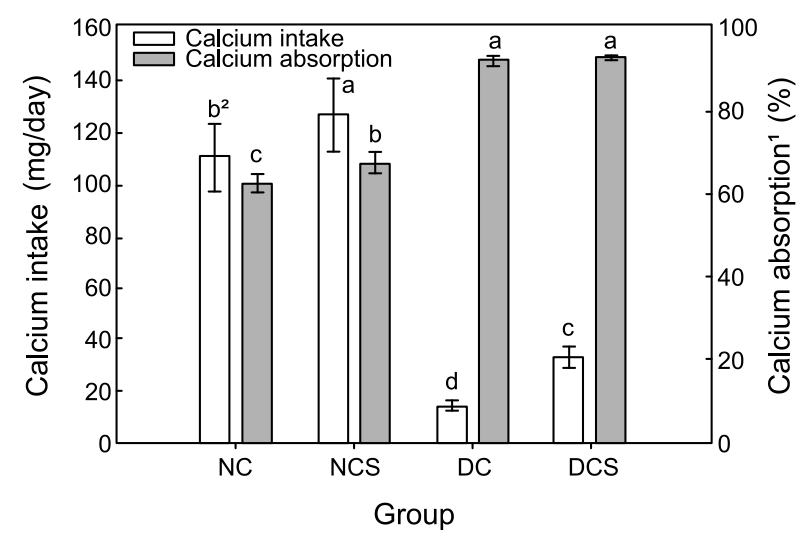

Fig. 2. Calcium intake and calcium absorption for 2 days at 4 th week, All data were expressed as mean \pm SD of 12 rats per group.; 1 This value was calculated as '[calcium intake-(fecal calcium excretion+Urinary calcium excretion)]/ calcium intake $\times 100^{\prime}$.; 2 Values within column with different superscript letters are significantly different at $P<0.05$.

$13.93 \pm 1.74 \mathrm{mg}$ 보다 약 8 배 정도 높았다. 추출물을 첨가한 NCS 군과 DCS군은 $126.90 \pm 14.11 \mathrm{mg}, 33.05 \pm 4.10 \mathrm{mg}$ 으로 나타나 각각의 대조군 $(\mathrm{NC}, \mathrm{DC})$ 의 칼슘섭취량보다 유의적으로 높은 것을 알 수 있었다. 칼슘 흡수율은 체내 잔존하는 칼슘량과 칼슘섭취량에 대한 백분율이며, 체내 잔존하는 칼슘량은 칼슘 섭취량에서 변과 뇨로 배출된 칼슘량을 감하여 구해졌다. 각 그룹의 칼슘흡수율은 NC군 $62.45 \pm 2.18 \%, \mathrm{NCS}$ 군 $67.56 \pm$ $2.67 \%, \mathrm{DC}$ 군 $92.36 \pm 1.16 \%, \mathrm{DCS}$ 군 $93.06 \pm 0.40 \%$ 로 나타났고, 정상사료군 $(\mathrm{NC}, \mathrm{NCS})$ 이 칼슘결핍사료군 $(\mathrm{DC}, \mathrm{DCS})$ 보다 다소 낮았다. 칼슘흡수율을 각 사료군 안에서 대조군과 비교 해보면, 칼슘결핍사료군 안에서는 유의적인 차이가 없었으나, 정상사 료군 안에서 추출물을 첨가한 NCS군의 칼슘흡수율이 추출물 을 첨가하지 않은 $\mathrm{NC}$ 군보다 유의적으로 높게 나타났다. 
골 형성도

골 형성 정도를 알아보기 위하여 대퇴골을 지표로 습중량 (Wet Weight), 길이 (Length), 직경 (Diameter), 골 밀도 (Bone Mineral Density, BMD), 골 무기질함량 (Bone Mineral Content, $\mathrm{BMC}$ )을 측정하였다 (Table 3). 모든 군의 대퇴골 습중량은 칼슘섭취량에 의존하는 경향을 보였다. 칼슘섭취량이 높았던 정상사료군 $(\mathrm{NC}, \mathrm{NCS})$ 의 습중량이 칼슘섭취량이 낮았던 칼슘 결핍사료군 $(\mathrm{DC}, \mathrm{DCS})$ 보다 높게 나타났다. 각 대조군과 비교 해 보면, 정상사료군 안에서 $\mathrm{NC}$ 군과 $\mathrm{NCS}$ 군 사이에는 통계적 유의차가 없었고, 칼슘결핍사료군 안에서는 $\mathrm{DCS}$ 군의 습중량 이 $\mathrm{DC}$ 군 보다 유의적으로 높게 나타났다. 대퇴골의 길이와 직경은 $\mathrm{DC}$ 군만 유의적으로 낮았고, $\mathrm{NC}$ 군, $\mathrm{NCS}$ 군, $\mathrm{DCS}$ 군 사이에는 유의적인 차이를 보이지 않아 같은 결과를 나타내었 다. 골 밀도 $\left(\mathrm{g} / \mathrm{cm}^{2}\right)$ 는 골 무기질함량 $(\mathrm{g} / \mathrm{cm})$ 을 바탕으로 단위 면적당 골량으로 환산되어졌기 때문에 수치만 달라지고 같은 결과를 나타낸다. 골 밀도와 골 무기질함량은 정상사료군 $(\mathrm{NC}, \mathrm{NCS})$ 이 칼슘결핍 사료군 $(\mathrm{DC}, \mathrm{DCS})$ 보다 유의적으로 높게 나타났다. 각 대조군과의 비교에서는 정상사료군 안에서 $\mathrm{NC}$ 군과 $\mathrm{NCS}$ 군 사이 유의차는 없었고, 칼슘결핍군 (DC, DCS) 안에서 추출물을 첨가한 $\mathrm{DCS}$ 군의 골 밀도와 골 무기질함량이 첨가하지 않은 $\mathrm{DC}$ 군 보다 유의적으로 높게 나타나 습중량과 유사한 결과를 나타내었다.

Table 3. Wet weight, length, diameter, bone mineral density and bone mineral content of femur

\begin{tabular}{cccccc}
\hline Groups & $\begin{array}{c}\text { Wet wt. } \\
(\mathrm{g})\end{array}$ & $\begin{array}{c}\text { Length } \\
(\mathrm{mm})\end{array}$ & $\begin{array}{c}\text { Diameter } \\
(\mathrm{mm})\end{array}$ & $\begin{array}{c}\mathrm{BMD}^{1} \\
\left(\mathrm{~g} / \mathrm{cm}^{2}\right)\end{array}$ & $\begin{array}{c}\mathrm{BMC}{ }^{2} \\
(\mathrm{~g} / \mathrm{cm})\end{array}$ \\
\hline NC & $0.72 \pm 0.02^{\mathrm{a} 3}$ & $29.57 \pm 0.27^{\mathrm{a}}$ & $2.96 \pm 0.04^{\mathrm{a}}$ & $0.089 \pm 0.001^{\mathrm{a}}$ & $0.178 \pm 0.006^{\mathrm{a}}$ \\
NCS & $0.76 \pm 0.02^{\mathrm{a}}$ & $29.58 \pm 0.05^{\mathrm{a}}$ & $2.90 \pm 0.02^{\mathrm{a}}$ & $0.090 \pm 0.001^{\mathrm{a}}$ & $0.179 \pm 0.003^{\mathrm{a}}$ \\
DC & $0.60 \pm 0.01^{\mathrm{c}}$ & $28.76 \pm 0.17^{\mathrm{b}}$ & $2.73 \pm 0.02^{\mathrm{b}}$ & $0.063 \pm 0.001^{\mathrm{c}}$ & $0.126 \pm 0.008^{\mathrm{c}}$ \\
DCS & $0.66 \pm 0.01^{\mathrm{b}}$ & $29.50 \pm 0.11^{\mathrm{a}}$ & $2.89 \pm 0.02^{\mathrm{a}}$ & $0.066 \pm 0.001^{\mathrm{b}}$ & $0.131 \pm 0.001^{\mathrm{b}}$ \\
\hline
\end{tabular}

All data were expressed as mean $\pm \mathrm{SD}$ of 12 rats per a group.; ${ }^{1}$ Bone mineral density

${ }^{2}$ Bone mineral content

${ }^{3}$ Values within column with different superscript letters are significantly different at $P<0.05$.

Table 4. Calcium, phosphorus, osteocalcin contents and alkaline phosphatase activity in serum

\begin{tabular}{ccccc}
\hline Groups & $\begin{array}{c}\text { Calcium } \\
(\mathrm{mg} / \mathrm{dL})\end{array}$ & $\begin{array}{c}\text { Phosphorus } \\
(\mathrm{mg} / \mathrm{dL})\end{array}$ & $\begin{array}{c}\text { Osteocalcin } \\
(\mathrm{ng} / \mathrm{mL})\end{array}$ & $\begin{array}{c}\text { ALPase } \\
(\mathrm{IU} / \mathrm{L})\end{array}$ \\
\hline NC & $10.45 \pm 0.09^{\mathrm{ab} 1}$ & $6.87 \pm 0.19^{\mathrm{b}}$ & $6.65 \pm 0.14^{\mathrm{c}}$ & $477.08 \pm 30.46^{\mathrm{c}}$ \\
NCS & $10.62 \pm 0.10^{\mathrm{a}}$ & $7.52 \pm 0.19^{\mathrm{a}}$ & $7.44 \pm 0.30^{\mathrm{c}}$ & $460.04 \pm 43.09^{\mathrm{c}}$ \\
DC & $10.06 \pm 0.08^{\mathrm{c}}$ & $7.63 \pm 0.25^{\mathrm{a}}$ & $15.34 \pm 0.62^{\mathrm{a}}$ & $946.25 \pm 59.26^{\mathrm{a}}$ \\
DCS & $10.28 \pm 0.08^{\mathrm{bc}}$ & $7.16 \pm 0.20^{\mathrm{ab}}$ & $11.47 \pm 0.38^{\mathrm{b}}$ & $647.92 \pm 26.02^{\mathrm{b}}$ \\
\hline
\end{tabular}

All data were expressed as mean $\pm \mathrm{SD}$ of 12 rats per a group.; ${ }^{1}$ Values within column with different superscript letters are significantly different at $P<0.05$.
혈청분석

혈청칼슘, 인, Osteocalcin농도와 Alkaline Phosphatase (ALPase)활성은 Table 4와 같다. Jeong et al. (1997)의 보고 에 따르면, 혈청칼슘농도는 내적, 외적 요인에 대하여 항상성 (Homeostasis)을 유지하기 때문에 Rat를 대상으로 한 실험에서 요인을 아무리 변화시켜도 $7.2 ~ 13.9 \mathrm{mg} / \mathrm{dL}$ 에 있었다고 하였 다. 본 실험에서의 혈청칼슘농도는 $10.06 \pm 0.08 \sim 10.62 \pm 0.10$ $\mathrm{mg} / \mathrm{dL}$ 범위에 있었으며, 정상사료군 $(\mathrm{NC}, \mathrm{NCS})$ 이 칼슘결핍사 료군 $(\mathrm{DC}, \mathrm{DCS})$ 보다 유의적으로 높게 나타났다. 각 대조군과 의 비교에서는 정상사료군 안에서 $\mathrm{NC}$ 군과 $\mathrm{NCS}$ 군 사이, 칼슘 결핍사료군 안에서 $\mathrm{DC}$ 군과 $\mathrm{DCS}$ 군 사이 혈청칼슘농도는 유 의적인 차이를 보이지 않았다. 정상적인 흰쥐의 혈청인 농도 는 3.11 11.0 mg/dL라고 보고되어 있는 바 (Mitruka and Rawnsley, 1981), 본 실험에서 모든 군의 혈청인의 농도 범위는 $6.87 \pm 0.19 \sim 7.63 \pm 0.25 \mathrm{mg} / \mathrm{dL}$ 로 정상범위에 있었으며, 추출물 첨가와 관련된 별다른 양상은 찾아볼 수 없었다. 골아세포 (osteoblasts)로부터 생성되는 Osteocalcin은 골 안에서 Hyproxyapatite, 칼슘등과 단단히 결합되어 있으며, 골 형성과 정 중 일부가 혈액으로 방출된다. ALPase는 간과 골에서 대부 분 생성되며 골의 성장과 골절 (Fracture)시에 혈액으로 방출된 다. 따라서, Osteocalcin함량과 ALPase활성은 골 성장 정도를 간접적으로 판단하는 생화학적 지표로 사용될 수 있다 (Dorota and Danuta, 1997; Lee at al., 1997). 본 실험에서 Osteocalcin농 도와 ALPase활성은 NCS군의 Osteocalcin농도가 NC군 보다 약간 높은 것을 제외하고는 모든 군에서 유사한 경향을 나타 내었다. Osteocalcin농도와 ALPase활성은 칼슘섭취량에 반비 례 하였고, 정상사료군이 칼슘결핍사료군 보다 훨씬 낮았다. 각 대조군과 비교 시 특이한 점은 정상사료군 안에서 추출물 을 첨가한 $\mathrm{NCS}$ 군과 첨가하지 않은 $\mathrm{NC}$ 군 사이 유의적인 차이 가 없었던 반면, 칼슘결핍군 안에서 추출물을 첨가한 $\mathrm{DCS}$ 군 이 첨가하지 않은 $\mathrm{DC}$ 군보다 Osteocalcin농도와 ALPase활성이 유의적으로 많이 떨어진 것을 발견할 수 있었다.

\section{고 찰}

Reinhart와 Mahan (1986)은 식이 칼슘량이 높아질수록 돼지 의 성장기 체중증가량이 감소하며, Koba et al. (2001)과 Miura et al. (1999)은 흰쥐에서 소량 또는 과량 칼슘섭취는 체중증가 량과 사료효율을 감소시킨다고 하였다. 본 실험에서 사료섭취 량은 칼슘섭취량과 관계없이 군간에 유의적인 차이가 나타나 지 않았다. 또한, 칼슘섭취량은 추출물이 첨가된 사료군 $(\mathrm{NCS}$, $\mathrm{DCS})$ 이 추출물이 첨가되지 않은 대조군 사료군 $(\mathrm{NC}, \mathrm{DC})$ 보다 약 $0.16 ~ 0.19 \%$ 가량 높았음에도 체중증가량과 사료효율 에서 추출물첨가군 $(\mathrm{NCS}, \mathrm{DCS})$ 이 각각의 대조군 $(\mathrm{NC}, \mathrm{DC})$ 보 다 유의적으로 높게 나타났다. 앞선 연구결과들에 비추어 볼 때, 이는 암컷흰쥐는 실험기간 동안 추출물에 대하여 거부반 응을 일으키지 않았으며, 추출물이 성장기 암컷흰쥐의 체중증 가와 사료효율에 긍정적인 영향을 미쳤기 때문이라 할 수 있 겠다. 
식이를 통한 칼슘은 위에서 처음 용해되고 소장에서 흡수된 다. 흡수된 칼슘은 혈액을 통하여 새로운 골 형성, 체내 대사에 사용, 신장에서 재 흡수되며, 일정량 이상의 칼슘은 대변과 소변으로 배설된다 (Kumar, 1995). 칼슘의 흡수는 호르몬과 보조인자들에 의하여 조절되며, 칼슘섭취량이 낮을 경우 활발 한 수송으로 흡수율이 증가되지만, 필요이상의 양이 되면 배 출이 늘어나게 된다 (Heaney et al., 1990). 본 실험에서 칼슘흡 수율은 칼슘결핍사료군 $(\mathrm{DC}, \mathrm{DCS})$ 이 정상사료군 $(\mathrm{NC}, \mathrm{NCS})$ 보다 높게 나타나 칼슘섭취량이 낮아질수록 칼슘흡수율이 증가되는 경향을 보여 위 연구결과들과 잘 일치되었다. 칼슘 흡수율을 각 대조군과 비교 할 경우, 정상사료군 안에서 $\mathrm{NCS}$ 군은 $67.56 \pm 2.67 \%$ 로 $\mathrm{NC}$ 군 $62.45 \pm 2.18 \%$ 보다 유의적으로 높 게 나타났고, 칼슘결핍사료군 안에서도 역시 통계적인 차이는 없었지만, 추출물을 첨가한 $\mathrm{DCS}$ 군 $(93.06 \pm 0.40 \%)$ 이 $\mathrm{DC}$ 군 $(92.36 \pm 1.16 \%)$ 보다 약간 높게 나타나 추출물의 첨가가 칼슘 흡수율에도 긍정적인 영향을 미친 것으로 보였다. 대퇴골의 형성도에서는 습중량, 골 밀도, 골 무기질함량이 모두 비슷한 경향을 보였다. 정상사료군이 칼슘결핍사료군 보다 유의적으 로 높게 나타났고, 각 대조군과 비교 시 칼슘결핍군 안에서는 $\mathrm{DCS}$ 군이 $\mathrm{DC}$ 군 보다 높았던 반면, 정상사료군 안에서는 $\mathrm{NCS}$ 군과 $\mathrm{NC}$ 군 사이 유의적인 차이를 보이지 않았다. 이것은 $\mathrm{NC}$ 군 사료조성 내에 충분한 칼슘량이 존재하여 성장기 동안 이미 최대 골량에 달하였기 때문이라 사료된다. 혈청칼슘과 인 농도는 모든 군이 정상범위에 있었으며, 추출물 첨가와 관련된 양상을 찾아보기는 힘들었다. Osteocain농도와 APLase활성은 칼슘결핍군의 Osteocalcin농도와 ALPase활성 이 정상사료군보다 훨씬 높게 나타나, 칼슘결핍군은 정상사료 군에 비하여 골 성장이 완전하지 않으며, 현재까지도 진행중 인 것으로 보였다. 특히, Osteocain농도와 APLase활성에서 주 목할 부분은 추출물을 첨가한 DCS군의 Osteocalcin농도와 APLase활성이 DC군에 비하여 현저히 떨어졌다는 점이다. 이 와같은 결과들을 바탕으로 괭생이모자반 젖산추출물은 성장 기 암컷흰쥐의 체중, 사료효율, 칼슘흡수율, 골 형성도등 대부 분 증가 시켰다는 것을 알 수 있었고, 추출물은 성장기 암컷흰 쥐의 성장과 골 형성에 긍정적인 영향을 미쳤다고 사료된다. 또한 여기에는 과제가 남아있다. 해조류가 설치류 골 대사에 긍정적인 영향을 미친다는 보고는 다수 존재하나 아직 확실한 mechanism은 밝혀지지 않았다. Yamaguchi et al. (2001)은 흰쥐 의 Femoral Methaphysical Tissue상에서 골형성 (Bone Formation)과 골석회화 (Bone Calcification)에 6종의 해조류의 물 추출물 가운데 Sargassum horneri가 가장 효과적이며, 그 속에는 활성이 있는 물질이 존재한다 하였고, Uchiyama et al. (2004)은 Sargassum horneri 물 추출물속 골 석회화에 효과 를 가지는 활성 물질은 분자량 $(\mathrm{MW}) 1000$ 근처에 존재한다 하였다. 본 실험에 추출물은 대부분 탄수화물 $(41.27 \%)$ 과 회분 (36.46\%)으로 구성되어 있는데, 갈조류의 탄수화물은 대부분 비소화성 식이섬유로 소장에서 무기질과 미량원소들과 결합 하여 체내흡수를 낮추게 하고, 분자 내 이온화된 작용기의 수에 따라 그 영향력이 차이가 난다고 보고되어 있다
(Bosscher et al., 2001; Fuchs et al., 1993). 한편, Medeiros et al. (2004) 은 체내 $\mathrm{Fe}$ 결핍이 장기간 지속되면 골 밀도에 직접 적으로 좋지 않은 영향을 미치며, Kawamura et al. (2003) 은 Rabbit 뼈 형성시 $\mathrm{Zn}$ 이 긍정적인 영향을 미친다고 보고하였다. Ynsa et al. (2006) 은 난소절제 후 $\mathrm{S}, \mathrm{K}, \mathrm{Fe}, \mathrm{Zn}$ 과 호르몬 공급제 의 적절한 조화가 뼈 손실을 늦출 수 있다고 보고 하였고, 특히, Carlisle (1986)는 저칼슘 식이 (Calcium Content : 0.08\%) 와 고칼슘 식이 (Calcium Content : $0.4 \sim 1.2 \%$ )를 시킨 흰쥐의 정강이 뼈를 확인해본 결과 칼슘의 농도보다 $\mathrm{Si}$ 농도에 의존하 여 회분함량과 칼슘의 함량이 높아진다 하였다. 앞선 연구 결과들에 비추어 보면, 본 모자반 추출물은 유기화합물에 의 한 것이라기 보다 추출물 안에 존재하는 다양한 미네랄에 의한 상호작용으로 사료되며, 다양한 무기질을 조체에 함유하 고 있는 해조는 칼슘대사와 관련하여 좋은 식재료가 될 것으 로 여겨진다.

\section{참고문헌}

AOAC. 1990. Official Method of Analysis. $15^{\text {th }}$ ed. Association of Official Analytical Chemists, Washington, DC, U.S.A., Vol 17, 868-931.

Bosscher D, Van Caille-Bertland M and Deelstra H. 2001. Effect of Thickening Agents, Based on Soluble Dietary Fiber, on Availability of Cacium, Iron and Zinc from Infant Formulas. Nutrition 17, 614.

Bougle D, Boudey M, Arban D, Bureau F, Neuville D and Orosdowsky M. 1996. In Vivo Study of The Absorption of Seaweed Minerals by Perfused Rat Intestine. Short Communication. Phytother Res 10. 325-326.

Carlisle EM. 1986. Silicon as an Essential Trace Element in Animal Nutrition In: Silicon Biochemistry. Ciba Foundation Symposium 121, 123-139

Cho DM, Kim DS, Lee DS, Kim HR and Ryeun JH. 1995. Trace Components and Functional Saccharides in Seaweed-1:Change in Proximate Composition and Trace Elements According to The Harvest Season and Places. Bull Kor Fish Soc 29, 49-59.

Dorota PJ and Danuta Z. 1998. Osteocalcin as a Biochemical Marker of Bone Turnover. Review. Nephrology 4, 339-346.

Fuchs GJ, Farris RP and Deweir M. 1993. Iron Status and Intake of Older Infants Fed Formula vs Milk with Cereal. Am J Clin Nutr 58, 343.

Heaney RP, Weaver CM and Fitzsimmons ML. 1990. Influence of Calcium Load on Absorption Fraction. J Bone Mineral Research 5, 1135-1138.

Jeong HK, Kim JY and Lee HS. 1997. The Effect of Dietary Calcium and Phosphatate Levels on Calcium 
and Bone Metabolism in Rat. Kor Nutr Soc 30, 813-824

Kawamura H, Ito A, Muramatsu T, Miyakawa S, Ochiai $\mathrm{N}$ and Tateishi T. 2003. Long-Term Implantation of Zinc-Releasing Calcium Phosphate Ceramics in Rabbit Femora. J Biomed Master. Res 67A, 468-674.

Koba T, Matsui T and Yano H. 2001. Effect of Calcium Carbonate Exes on Some Mineral Metabolism in Young Rats. J Jap Soc Magnesium Res 20, 11-20.

Korea Centers for Disease Control and Prevention (KCDCP). 2008. 2007 National Health StatisticsNational Diet and Nutrition Survey. Seoul, Korea, Kumar R. 1995. Calcium Transport in Epitelial Cells of The Intestine and Kidney. J Cell Biochem 57, 392-398.

Kwak YH, Bai SC and Kim DJ. 2010. Estimated Availability and Major Minerals ( $\mathrm{Ca}, \mathrm{P}$ and $\mathrm{Mg}$ ) Contents Bound Neutral Detergent Fiber (NDF) of Seaweeds. J Kor Soc Food Sci Nutr 39, 1073-1077.

Lee CK, Choi JS, Jeong YJ, Byun HG and Kim SK. 1997. The Properties of Natural Hydroxyapatite Isolated from Tuna Bone. Bull Kor Fish Soc 30, 652-659.

Lee JG, Lim YS, Joo DS and Jeong IH. 2002. Effects of Diet with Sea Tangle(Kjellemaniella Crassifolia) an Calcium Absorption and Feces in Rats. J Kor Fish Soc 35, 601-607.

Levrat, MA, Remesy, C and Demigne, C, 1991, High Propionic Acid Fermentations and Mineral Accumulation in the Cecum of Rats Adapted to Different Levels of Inulin, J Nutr 121, 11, 1730-1737. Medeiros DM, Stoecker B, Plattner A, Jennings D and Haub M. 2004. Iron Deficiency Negatively Affects Vertebrae and Femurs of Rats Independently of Energy Intake and Body Weight. J Nutr 134, 3061-3067.

Mitruka BM and Rawnsley HM. 1981. Clinical Biochemical and Hematological Reference Value in Normal Experimental Animals and Normal Humans. 2ed, Masson Pub., New York, U.S.A., 160.

Miura T, Matsuzaki H, Suzuki K and Goto S. 1999. Long-Term High Intake of Calcium Reduces Magnesium Utilization in Rats. Nutr Res 19, 13631369.

Reeves PG, Nielsen FH and Fahey GC. Jr. 1993. AIN-93 Purified Diets for Laboratory Rodents: Final Report of The American Institute of Nutrition ad Hoc Writing Committee on The reformulation of the AIN-76A Rodent Diet. J Nutr 123, 1939-1951.

Reinhart GA and Mahan DC. 1986. Effect of Various Calcium, Phosphorus Ratio at Low and High Dietary Phosphorus for Starter, Grower and Finishing Swine. J Animal Sci 63, 457-466.

Ruperez P. 2002. Mineral Content of Edible Marine Seaweed. Food Chem 79, 23-26.

Uchiyama S, Hashizume M, Hokari Y, Nakagawa T, Igarashi A and Yamaguchi M. 2004. Characterization of Active Component in Marine Alga Sargassum honeri Extrat in Stimulating Bone Calcification In Vitro. J. Health Sci 50, 634-639.

Weaver CM. 2000. The growing Years and Prevention of Osteoporosis in Late Life. Proceedings of The Nutrition Society 59, 303-306.

Yamaguchi M, Hachiya S, Hiratsuka S and Suzuki T. 2001. Effect of Marine Algae Extract on Bone Calcification in the Femoral-Metaphyseal Tissues of Rats: Anabolic Effect of Sargassum honeri. J Health Sci 47, 533-538.

Ynsa MD. Ager FJ, Alvess LC, Zubeldia MA, Millan JC and Pinheiro T. 2006. Elemental Distributions in Femoral Bone of Rat under Osteoporosis Preventive Treatments. J Microscopy 224, 298-305.

2010년 11월 15일 접수

2011년 1월 27일 수정

2011년 2월 10일 수리 